\title{
Rehun olomuodon ja energiaväkevyyden sekä rodun ja sukupuolen vaikutus lihasikojen kasvatuksessa
}

Mikko Tuori, Hilkka Siljander-Rasi ja Kirsi Partanen

MTT Kotieläintuotannon tutkimus, sianlihan ja siipikarjan tuotanto, Tervamäentie 179, 05840 Hyvinkää, etunimi.sukunimi@mtt.fi

\section{Tiivistelmä}

Kahdessa ruokintakokeessa lihasioilla vapaalla ruokinnalla tutkittiin rehun olomuodon (jauho, rae), energiaväkevyyden $(0,93$ ja $1,08 \mathrm{RY} / \mathrm{kg})$ sekä rodun ja sukupuolen vaikutusta rehunsyöntiin, kasvuun, rehun hyväksikäyttöön ja teurastuloksiin. Osakokeessa 1 porsaiden isärodut olivat maatiainen tai yorkshire (MY) tai norjanduroc x maatiais -risteytys (DM). Emakot olivat maatiais-yorkshire -risteytyksiä. Osakokeessa 2 näiden rotujen lisäksi oli HM-risteytykset, joiden isärotuna oli puhdasrotuinen ruotsinhampshire. Siat kasvatettiin parikarsinoissa sukupuolet erikseen. Sikoja oli yhteensä 376, joista MY-sikoja oli 140, DM-sikoja 144 ja HM-sikoja 92 kpl. Kussakin roturyhmässä oli imisiä ja leikkoja suunnilleen sama määrä. Eläimet otettiin kokeeseen n. 70 päivän iässä, jolloin keskimääräinen elopaino oli 26,6 kg. Keskimäärin 80 päivän koejakson jälkeen eläimet menivät teuraaksi, elopaino oli 112,8 kg. Siat kasvatettiin parikarsinoissa imisät ja leikot erikseen. Eläimet punnittiin viikon välein, samoin karsinan rehunkulutus mitattiin viikon välein. Rehut olivat vehnä-soijarouhepohjaisia. Ero energiaväkevyydessä saatiin korvaamalla vehnää joko ohrarehulla tai tärkkelyksellä ja pienellä määrällä rypsiöljyä. Toinen osa rehuseoksesta rakeistettiin. Sioilla oli kaksivaiheruokinta.

Rehun rakeistus vähensi rehun syöntiä. Koska kasvunopeuteen ei ollut vaikutusta, rehun hyväksikäyttö oli parempi verrattuna jauhoruokintaan. Rakeistuksen ja rodun välillä oli syönnissä merkitsevä yhdysvaikutus. MY-sioilla rakeistus vähensi syöntiä enemmän kun HM-sioilla, ja DM-sioilla rakeistus ei vaikuttanut rehun syöntiin. Rehun energiaväkevyyden lisääminen lisäsi kasvua, vähensi rehun syöntiä ja paransi hyväksikäyttöä (kgKA/kasvukg). Rehuyksiköissä mitattuna hyväksikäytössä ei ollut eroa. Väkevä dieetti lisäsi myös silavan paksuutta ja vähensi teurastappiota, mutta vähensi lihaprosenttia. Leikot kasvoivat imisiä nopeammin, mutta söivät rehua enemmän, ja rehun hyväksikäyttö oli huonompi kuin imisillä. Leikot myös rasvoittuivat enemmän ja lihaprosentti jäi pienemmäksi verrattuna imisiin. Kolmiroturisteytyksistä HM-risteytykset kasvoivat paremmin kuin DM-risteytykset. DM- ja MYristeytysten välillä ei ollut kasvussa eroa $(1106,1075,1073 \mathrm{~g} / \mathrm{pv})$. Sekä DM- että HM-risteytykset söivät enemmän rehua $(2,63,2,56$ ja 2,38 kg KA/pv) ja käyttivät enemmän rehua kasvukiloa kohti kuin MYristeytykset $(2,37,2,38$ ja 2,27 kg KA/kasvukg, HM-, DM- ja MY-siat). HM- ja DM-siat rasvoittuivat enemmän, ja niiden lihprosentti pienempi kuin (58,0, 57,8 ja 59,3\%), mutta ulkofileen paksuus oli suurempi $(55,3,53,9$ ja 52,4 mm) kuin MY-sioilla.

Asiasanat

Lihasiat, sukupuoli, roturisteytys, duroc, hampshire, yorkshire, maatiainen, rakeistus, energia 


\section{Johdanto}

Kasvavan sian ad libitum eli vapaaehtoiseen rehunsyöntikykyyn vaikuttavat monet eläinperäiset tekijät kuten elopaino, sukupuoli, geneettiset tekijät kuten rotu, terveys sekä ympäristötekijät kuten ilmasto, sikalasysteemi, eläintiheys, rehun ominaisuudet (Noblet ja van Milgen 2004).

Rehun ominaisuuksista energiaväkevyys vaikuttaa merkittävästi rehun syönnin vaihteluun. Saadakseen energiantarpeensa tyydytettyä sika lisää rehun syöntiä, kun rehun energiaväkevyys alenee. Ravintokuitua (dietary fibre) sisältävät elintarviketeollisuuden sivutuotteet (vehnänlese, sokerijuurikasleike, ohrarehu) alentavat rehun energiaväkevyyttä. Vaikka lisääntynyt rehun ravintokuitupitoisuus ei välttämättä alenna ohutsuolisulavuutta, näennäistä kokonaissulavuutta ja nettoenergian saantia vähentää lisääntynyt endogeenisen aineen (valkuainen, rasva) eritys sonnassa (Wilfart ym. 2007). Toinen tässä tutkimuksessa mukana oleva rehun ominaisuus on rakeistus, jolloin rehupartikkelien hienontuminen ja kuumennus saattavat vaikuttaa sulavuuteen ja syöntiin (Noblet ja van Milgen 2004).

Suomessa lihasiat ovat yleensä risteytyksiä. Maatiais- ja yorkshire-risteytysten (MxY tai YxM) lisäksi ovat yleistymässä kolmiroturisteytykset, jolloin kolmantena rotuna on joko duroc (D) tai hampshire (H). Aiemmissa tutkimuksissa duroc-maatiais-yorkshire -kolmiroturisteytyssikojen (DMxMY) ja maatiaisyorkshire -kaksiroturisteytyssikojen (MxY) erot kasvussa olivat vähäiset (Alaviuhkola ym. 1998, SiljanderRasi 2005). DMxMY-sikojen rehun hyväksikäyttö yli $55 \mathrm{~kg}: n$ elopainossa oli heikompi ja ruhon rasvaisuus suurempi sekä lihaprosentti pienempi kuin MY-sikojen. DMxMY-pahnueissa syntyi 1 porsas enemmän ja vieroitettiin 1,2 porsasta enemmän kuin MY-pahnueissa (Siljander-Rasi 2005). Tanskassa maatiaisrotuiset siat pidättivät vähemmän valkuaista kuin puhdasrotuiset duroc- ja hampshirerotuiset siat. Viimeksi mainittujen välillä valkuaisen pidättymisessä ei ollut eroa (Tauson ym. 1998).

Tämän kokeen tavoitteena oli selvittää rehun olomuodon ja energiaväkevyyden vaikutus lihasikojen rehunsyöntiin, kasvuun ja rehun hyväksikäyttöön eläinaineksen ollessa maatiais x yorkshire -risteytyksiä, DM x MY- tai H x MY -risteytyksiä.

\section{Aineisto ja menetelmät}

Tutkimuksessa oli kaikkiaan 376 sikaa, jotka olivat kolmea eri roturisteytystä. MY-sikoja (isärotu maatiainen tai yorkshire) oli 140, DM-sikoja (isärotu norjanduroc x MY -risteytys) 144 ja HMsikoja (puhdas ruotsinhampshire) $92 \mathrm{kpl}$. Kaikkien porsaiden emät olivat maatiais-yorkshire risteytysemakoita. Siemennyksissä käytettiin usean karjun sperman seosta. Kussakin roturyhmässä oli suunnilleen yhtä paljon imisiä ja leikkoja, ja sukupuolet kasvatettiin erikseen pariruokinnalla.

Ruokintatekijät olivat faktoriaalisesti $2 \times 2$ muodossa: rehun olomuoto (jauho vs. rae) ja rehun energiaväkevyys ( 0,93 vs. $1,08 \mathrm{RY} / \mathrm{kg}$ rehua). Samasta pahnueesta imisät ja leikot arvottiin erikseen eri ruokintaryhmiin. Koe aloitettiin MY- ja DM -ristetyssioilla, ja jatkettiin seuraavana vuonna HMristeytyssioilla. Kokeen ensimmäisen osan (osakoe 1) alettua huomattiin, että rehuseosten fosforipitoisuus oli jäänyt suunniteltua pienemmäksi, koska sekoitusvaiheessa kivennäisseos oli vaihtunut hivenaineseokseksi. Sen tähden HM-sikojen kanssa otettiin uudestaan MY- ja DM-risteytykset kokeeseen (osakoe 2), ja muutettiin rehuseosten fosforipitoisuus suositusten mukaisiksi. Koska koerehuseoksiin ei tullut muita muutoksia, eikä fosforivajauksella ollut eläimiin vaikutusta, yhdistettiin osakokeet tulosten laskennassa. Kesken kokeen osakokeesta 1 poistettiin kolme karsinaa jalkavikojen ja huonon kasvun vuoksi ja osakokeesta 2 yksi karsina, koska toinen sika kuoli. Tulosten käsittelyssä poistettiin lisäksi kahden karsinan eläinten tiedot poikkeavan loppupainon (standardoitu residuaali 4-5) vuoksi.

Siat otettiin kokeeseen keskimäärin 70,0 päivän ikäisinä alkupainon ollessa $26,6 \mathrm{~kg}$. $\mathrm{Ne}$ oli vieroitettu n. neljän viikon iässä, jolloin keskimääräinen elopaino oli ollut 9,5 kg. Eläimet olivat kokeessa keskimäärin 80 päivää, ja paino kokeen lopussa oli 112,8 kg. Siat ruokittiin kaukaloista ruokahalun mukaan niin, että rehua oli aina tarjolla. Rehujäte poistettiin kaukalosta kerran päivässä. Eläimet punnittiin viikon välein, ja rehunkulutus laskettiin viikon jaksoille.

Dieetin energiaväkevyys muutettiin korvaamalla vehnä-soijapohjaisen ruokinnan vehnää joko kuitupitoisella ohrarehulla tai energiapitoisella ohratärkkelyksellä ja pienellä määrällä kasviöljyä. Loppukasvatusrehujen energiaväkevyys pysyi samana, mutta valkuaispitoisuus oli alempi. Rehujen 
aminohappo- ja kivennäispitoisuus oli suositusten mukainen (MTT 2004). Rehut valmistettiin MTT:n Jokioisten rehusekoittamossa. Vehnä oli karkeaksi jauhettua $(4,5 \mathrm{~mm})$. Rehut sekoitettiin ja rakeinen rehu rakeistettiin (rakeen läpimitta 4,0 mm) MTT:n Jokioisten rehusekoittamossa. Osakokeessa 1 ei käytetty höyryä, mutta osakokeessa 2 oli höyryrakeistus. Ohrarehun sulavien aminohappojen pitoisuudet laskettiin käyttäen rehutaulukoista ohrarehun aminohappopitoisuuksia ja ohran sulavuuksia (MTT2004). Näin laskettuna ohrarehu sisälsi ohutsuolisulavaa lysiiniä 3,46 , metioniinia 1,77 , kystiiniä 1,57 ja treoniinia 3,00 g/kg KA. Lisättyjen aminohappojen ohutsuolisulavuutena käytettiin $100 \%$. Rehuseosten suunnittelussa rehujen rehuarvoina käytettiin rehutaulukon arvoja (MTT2004).

Rehusekoittamosta rehut tuotiin 1000 kg:n konteissa, joista otettiin näytteet kuiva-ainemääritykseen sekä analyysinäytteet, jotka säilytettiin kokeiden ajan pakastettuina. Kokeen päätyttyä rehukohtaiset näytteet yhdistettiin kahdeksi näytteeksi per koe. Näytteistä analysoitiin tuhka, raakavalkuainen, raakarasva, kalsium, fosfori sekä raakakuitu (osakoe I) tai NDF ja ADF (osakoe II). Rehujätteet kerättiin karsinakohtaisesti päivittäin ja yhdistettiin siten, että viikossa tuli kaksi jätenäytettä per karsina. Näytteet säilytettiin pakastettuina kunnes niistä määritettiin kuiva-ainepitoisuus.

Siat lähetettiin teuraaksi, kun karsinan sikojen keskipaino ylitti 107 kg. Ruhoista määritettiin silavan paksuus ja lihaprosentti Hennessy GP-laitteella sekä PSE-lihaisuus mittaamalla nesteen heijastumaa lihaksen pinnasta. Teurashintoina käytettiin vuoden 2006 keskimääräisiä hintoja eri laatuluokissa (Tike 2007).

Tulosten tilastollinen analysointi tehtiin SAS:n Mixed-ohjelmalla. Kasvu, rehunkulutus ja rehunhyväksikäyttö laskettiin karsinakeskiarvoista. Varianssianalyysin sekamallissa kiinteinä tekijöinä olivat rotu, sukupuoli, rehun olomuoto ja rehun energiaväkevyys. Osakoe oli satunnaistekijänä. Teurastiedot käsiteltiin yksilöhavainnoista. Tällöin satunnaistekijäksi kokeen lisäksi tuli karsina koetekijän sisällä: karsina (isärotu*sukupuoli*olomuoto*energiaväkevyys). Luokitellut muuttujat testattiin khii ${ }^{2}$ testillä. Rehun syöntiä mallinnettiin ei-lineaarisilla malleilla.

Taulukko 1. Kokeessa käytettyjen rehujen raaka-aineet ja analysoitu koostumus ${ }^{1)}$

\begin{tabular}{|c|c|c|c|c|}
\hline & \multicolumn{2}{|c|}{ Alkukasvatusrehut } & \multicolumn{2}{|c|}{ Loppukasvatusrehut } \\
\hline Rehun energiaväkevyys, ry $/ \mathrm{kg}$ & 0,93 & 1,08 & 0,93 & 1,08 \\
\hline Vehnä & 608,9 & 450,6 & 627,8 & 518,5 \\
\hline Soijarouhe & 156,7 & 278,8 & 108,3 & 220,2 \\
\hline Ohrarehu & 200,0 & & 234,1 & \\
\hline Ohratärkkelys & & 200,0 & & 200,0 \\
\hline Rypsiöljy & & 30,0 & & 26,0 \\
\hline Lysiini & 3,9 & 3,1 & 2,2 & 1,3 \\
\hline Metioniini & 0,8 & 1,3 & & 0,1 \\
\hline Treoniini & 1,0 & 0,9 & 0,2 & \\
\hline Kivennäis- hivenaineet & 28,8 & 35,4 & 27,4 & 33,9 \\
\hline \multicolumn{5}{|l|}{ Kemiallinen koostumus } \\
\hline Kuiva-aine, g/kg & 892 & 893 & 893 & 894 \\
\hline \multicolumn{5}{|l|}{ Kuiva-aineessa, g/kg: } \\
\hline Tuhka & 60 & 63 & 54 & 60 \\
\hline Raakavalkuainen & 211 & 228 & 188 & 198 \\
\hline Raakarasva & 28 & 92 & 30 & 43 \\
\hline Raakakuitu & 65 & 29 & 71 & 27 \\
\hline $\mathrm{NDF}^{3)}$ & 216 & 92 & 220 & 88 \\
\hline Kalsium & 8,8 & 9,8 & 8,4 & 9,0 \\
\hline Fosfori & 6,5 & 7,3 & 6,5 & 7,0 \\
\hline
\end{tabular}




\section{Tulokset ja tulosten tarkastelu}

Rehun rakeistus

Rehujen kemiallisessa koostumuksessa koerehujen energiaväkevyyden ero näkyy raakarasva- ja kuitupitoisuudessa (Taulukko 1). Kokeessa 1 rehujen fosforipitoisuus jäi suunniteltua pienemmäksi, mutta kuitenkin kaikilla ruokinnoilla fosforin tarve tuli tyydytetyksi. Keskimääräinen P-pitoisuus alkukasvatusrehuissa oli 6,67 ja 7,19 osakokeissa 1 ja 2 sekä loppukasvatusrehuissa vastaavasti 6,41 ja $7,03 \mathrm{~g} \mathrm{P} / \mathrm{kg} \mathrm{KA}$.

Rehun rakeistus vähensi rehunkulusta, mutta ei vaikuttanut kasvuun (Taulukko 2). Alkukasvatuskaudella oli kasvussa yhdysvaikutus rakeistuksen ja energiaväkevyyden välillä $(\mathrm{P}<0,05)$. Täyttävällä ruokinnalla rehun energiaväkevyyden ollessa $0,93 \mathrm{RY} / \mathrm{kg}$ rakeista rehua saaneet siat kasvoivat paremmin kuin jauhoa saaneet (1048 ja 1019 g/pv). Väkevää rehua (1,08 RY/kg) saaneilla sioilla vastaavat kasvut olivat $1102 \mathrm{ja} 1130 \mathrm{~g} / \mathrm{pv}$.

Päivittäinen rehun kuiva-aineen kulutus oli rakeisia rehuja saaneilla sioilla 3,5\% pienempi kuin jauheisia rehuja saaneilla sioilla $(\mathrm{P}<0,01)$. Päivittäisessä rehunkulutuksessa oli erittäin merkitsevä yhdysvaikutus rehun olomuodon ja isärodun välillä. MY-sioilla rakeistetun rehun kulutus oli 7,7 \% pienempi kuin jauheisen rehun kulutus 2,29 vs. 2,48 kg KA/pv). HM-sioilla rakeistetun rehun syönti oli $3,4 \%$ pienempi $(5,58$ vs. $2,67 \mathrm{~kg} \mathrm{KA} / \mathrm{pv})$, mutta DM-sioilla rakeistuksella ei ollut vaikutusta rehun syöntiin (2,56 kg KA/pv kummallakin dieetillä).

Rehuhyötysuhde oli rakeisia rehuja saaneilla sioilla parempi kuin jauheisia rehuja saaneilla sioilla $(2,30$ ja 2,36 kg KA/kasvukg, $\mathrm{P}<0,01)$. Rakeistuksen positiivinen vaikutus rehun hyväksikäyttöön on usein, kuten tässäkin, perustunut rehun syönnin vähentymiseen kasvun kuitenkaan vähentymättä vastaavasti (O’Doherty ym. 2000), tai kasvun parantumiseen (Baird 1973, Nielsen 1986, Wondra ym. 1995a). Rakeistuksen syöntiä vähentävä vaikutus voi osittain johtua jauhorehun suuremmasta haaskaantumisesta kuten O'Doherty ym. (2000) ovat esittäneet. Kuitenkin dieetin (kuiva-aine tai orgaaninen aine) sulavuus on usein parantunut 5-9 \% (Wondra ym. 1995b, O’Doherty ym. 2000). Rakeistus on vähentänyt tärkkelyksen karkaamista sonnassa etenkin karkeaksi jauhetulla viljaruokinnalla. Hienoksi jauhetulla rehulla rakeistus on parantanut rehun hyväksikäyttöä vain vähän $(1,8 \%)$, mutta karkeaksi jauhetulla rehulla rehun hyväksikäyttö on parantunut 4-9 \% (Jørgensen ja Fisker 2006). Rakeistus lisää rehun hienousastetta, mikä myös parantaa sulavuutta, mutta lisää myös mahahaavariskiä etenkin, jos vilja on hienoksi jauhettua (Wondra ym. 1995b, Nielsen ja Ingwartsen 2000). Tässä kokeessa sikojen mahalaukkuja ei tutkittu, koska ulkonaisesti mahahaavatapauksia ei havaittu. Ilmeisesti vehnän karkeusaste oli riittävä. Rakeistuksessa osakokeiden 1 ja 2 välillä oli eroa höyryn käytössä. Skoch. (1983) eivät kuitenkaan havainneet höyryn käytöllä olleen vaikutusta kasvuun tai rehun hyväksikäyttöön. Rakeistuslämpötila oli tässä kokeessa vain. n.. $60^{\circ} \mathrm{C}$.

Rehun energiaväkevyys

Väkevää rehua saaneet siat söivät vähemmän ja kasvoivat nopeammin, ja koska tavoitepaino oli sama, lähtivät teuraaksi aikaisemmin kuin täyttävää rehua saaneet siat. Ero päivittäisessä rehunkulutuksessa oli $8,0 \%$, mutta rehun kokonaismäärässä ero oli $12,5 \%$ energiatasojen välillä $(\mathrm{P}<0,001)$. Väkevää rehua saaneet siat käyttivät kasvukiloa kohti 13,6 \% vähemmän rehua kuin täyttävää rehua saaneet $(\mathrm{P}<0,001)$. Kun hyväksikäyttö lasketaan rehuyksiköissä, energiatasojen välillä ei ollut eroa. Tämä osoittaa rehujen energiaväkevyyden olleen oikein arvioitu. Sikojen rasvoittuminen oli kuitenkin voimakkaampaa väkevää rehua saaneilla. Ruhon lihaprosentti ja laatuluokka olivat huonompia, mutta ulkofileen paksuus oli suurempi. Teurastustappio pienempi kuin täyttävää rehua saaneilla sioilla (Taulukko 2). Väkevää rehua saaneiden sikojen ruhoista oli parhaassa S-luokassa oli 31,1 \%, E-luokassa 58,4 \% ja U-luokassa (+ 1 sika R-luokassa) 10,5 \% . Vastaavat osuudet täyttävää rehua saaneilla olivat 44,1, 52,2 ja 3,8 \% (P<0,01). Koska loppupaino oli oli 0,8 kg suurempi väkevää rehua saaneilla, myös teuraspaino ja teurastili (euroa/sika) olivat suurempia huolimatta alemmasta lihan hinnasta (euroa/kg).

Väkevän rehun pienempi syönti johtuu sian ominaisuudesta pyrkiä syömään energian tarvetta vastaavasti. Tällöin syöntiä säätelee fysiologinen säätely. Suuremmasta täyttävän rehun syönnistä huolimatta siat eivät ole kyenneet syömään kasvupotentiaaliaan vastaavasti, koska päiväkasvu jäi 5,9 \% 
pienemmäksi kuin väkevää rehua saaneilla. Syöntiä on rajoittanut fysikaalinen säätely eli ruuansulatuskanavan tilavuus suhteessa sulamattoman rehun viipymiseen.

Sukupuolen vaikutus

Leikot kasvoivat nopeammin, söivät enemmän ja niiden kasvatusaika oli lyhyempi verrattuna imisiin (Taulukko 3), ja erot olivat suurempia loppukasvatuksessa kuin alkukasvatuksessa. Rehun hyötysuhde jäi leikoilla kuitenkin heikommaksi kuin imisillä (2,36 vs. 2,30 kg KA/kasvukg, $\mathrm{P}<0,01$ ), koska kasvu oli 5,9 $\%$ nopeampaa ja kasvatusaika 5,7 \% lyhyempi, mutta päivittäinen rehunkulutus 9,1\% suurempi imisiin verrattuna $(\mathrm{P}<0,001)$. Leikkojen teurastustappio ja silavan paksuus oli suurempi, ja lihaprosentti ja ulkofileen paksuus pienemmät imisiin verrattuna. Leikoista S-laatuluokassa oli 20,7 \%, E-luokassa $66,5 \%$ ja U-luokassa (+ yksi R-sika) 12,8 \%. Imisillä vastaava jakauma oli 54,3 \%, 44,2 \% ja 1,6 \%. (P<0,001). Teurashinta leikoilla oli $3 \%$ heikompi kuin imisillä.

\section{Roturisteytyksen vaikutus}

Alkukasvatuksessa kolmiroturisteytyssiat kasvoivat paremmin kuin kaksiroturisteytyssiat (1089, 1082 ja 1053 g/pv HM-, DM- ja MY-siat). Loppukasvatuksessa kuitenkin HM-siat kasvoivat paremmin kuin DM tai MY-siat (1128, 1066 ja $1091 \mathrm{~g} / \mathrm{pv})$. Kolmiroturisteytykset söivät enemmän (2,63, 2,56 ja 2,38 $\mathrm{kg} \mathrm{KA} / \mathrm{pv})$ ja rehun hyväksikäyttö oli huonompi $(2,37,2,38$ ja 2,24 kg KA/kasvukg) verrattuna kaksiroturisteytyksiin (Taulukko 3). Rehun olomuodon ja rodun välillä oli merkitsevä yhdysvaikutus

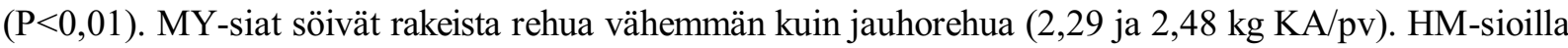
suunta oli sama, joskin ero pienempi (2,58 ja 2,67 kg KA/pv). DM-sioilla rakeistus ei vaikuttanut syöntiin (2,56 kg KA/pv molempia rehuja). Rehun hyväksikäyttöä rakeistus paransi MY-sioilla: MY-siat 2,16 ja 2,31; HM-siat 2,35 ja 2,39 sekä DM-siat 2,38 ja 2,39 kg KA/kasvukg rakeisella ja jauhorehulla, vastaavasti. Roduilla ei ollut vaikutusta teurastustappioon. Kolmiroturisteytykset rasvoittuivat enemmän ja niiden lihaprosentti oli pienempi verrattuna kaksiroturisteytyksiin. Ruhojen S-luokkaan MY-sioista pääsi 52,1 \%, DM-sioista 11,2 \% ja HM-sioista 28,3 \%. E-luokassa vastaava jakauma oli 44,3, 61,1 ja 63,0 \% sekä U-luokassa (yksi DM-sika R-luokassa) 3,6, 9,7 ja 8,7 \% (P<0,001). Lihan tilityshinta (euroa/kg) oli MY-sioilla parempi kuin DM- ja HM sioilla.

Aiemmissa rotuvertailuissa on ollut mukana MY-risteytysten kanssa vain DM-risteytykset. Tulokset ovat olleet saman suuntaisia: kasvussa ei eroa, rehun hyväksikäyttö on ollut MY-sioilla parempi (Alaviuhkola ym. 1998, Siljander-Rasi 2005). Rehun syöntikyky on suoraan yhteydessä lihas- ja rasvaskudoksen kasvuun, koska rasvakudoksen kasvu vaatii kolme-neljä kertaa enemmän energiaa kuin lihaskasvu (Nyachoti ym. 2004). Suuren lihaskasvupotentiaalin omaavilla sioilla rehunsyöntikyky on pienempi kuin sioilla, joilla on alempi lihasten kasvunopeus. Tanskassa tehdyssä rotuvertailussa (maatiaisen, duroc ja hamshire) pyrittiin maksimaaliseen proteiinin pidättymiseen. D- ja H-rodut olivat ylivertaisia maatiaiseen verrattuna. Kyseessä olivat puhdasrotuiset karjut, mutta koe osoitus rotujen välisistä kasvueroista (Tausen ym. 1998). Duroc- ja hamshire-risteytyksiä on verrattu myös Ruotsissa, mutta ilman valkoisia rotuja (yorkshire-maatiainen). Emät olivat LY-risteytyksiä (maatiainen-yorkshire), ja karjut joko ruotsinhampshireä tai tanskandurocia. Duroc-risteytysten kasvu ja rehun hyväksikäyttö olivat hieman paremmat, mutta hampshire-risteytyksiä kuoli tai hylättiin teurastuksessa vähemmän. Durockarjujen kasvuindeksi oli myös ollut parempi kuin hampshirekarjujen, mikä edelleen tasoitti rotujen välisiä eroja (Mattsson ym. 2005). Tässä kokeessa valkoisten MY-risteytysten ja värillisten DM ja HMristeytysten välillä ei lihaskasvussa ollut suuria eroja, koska MY:n pienempää teuraspainoa kompensoi suurempi lihaprosentti. Ilmeisesti kaksiroturisteytyksen tuottamaa heteroosin kasvua lisäävää vaikutusta kolmiroturisteytys ei enää huomattavasti lisää.

\section{Johtopäätökset}

Tulokset puoltavat energian annostelun lisäämistä alkukasvatuksessa vanhoihin suosituksiin verrattuna. Imisien ja leikkojen sekä kaksi- ja kolmiroturisteytysten energianormit tulisi eriyttää. Loppukasvatuksessa energian saannin rajoittaminen on välttämätöntä kaikkiern roturisteytysten leikoille. Ruhon rasvoittumisen perusteella rajoitustarve on suurempi värillisten kuin valkoisten rotujen sioille 
Nykyisiin ruokintasuosituksiin verrattuna tulokset puoltavat energian annostelun lisäämistä alkukasvatusvaiheessa. Energiasuositukset tulisi eriyttää imisille ja leikoille sekä kaksi- ja kolmiroturisteytyksille. Loppukasvatuksessa energian saannin rajoittaminen on välttämätöntä kaikkien roturisteytysten leikoille. Ruhon rasvoittumisen perusteella rajoitustarve on suurempi värillistenrotujen kuin valkoisten rotujen sioille.

\section{Kirjallisuus}

Alaviuhkola, Timo, Siljander-Rasi, Hilkka \& Suomi, Kaija. 1998. Duroc-risteytyksen vaikutus sianlihan laatuun. In: Ahlfors, K (toim.). Kotieläintieteen päivät 1998. Maaseutukeskusten Liiton julkaisuja no 924:327-332. Baird, D.M. 1973. Influence of pelleting swine diets on metabolizable energy, growth and carcass characteristics. Journal of Animal Science 36: 516-521.

Jørgensen, L. \& Fisker, B.N. 2006. Formaling og foderstruktur. Info Svin. Dansk Svineproduktion, DMA. 20.08.2006. 16 p. www.infosvin.dk/index.aspx?id=c3d0b6e5-ce4b-4254-8121-d95530587463\#a.

Jørgensen, L., Dahl, J., Borg Jensen, B. \& Damgaard Poulsen, H. 1999. Effekt af ekspandering, pelletering og fomalingsgrad på salmonella, produktionsresultater og mave-tarmsundhed hos slagtesvin samt på fytaseaktivitet og vitaminstabilitet i foder. Faglig Publikation, meddelelse nr. 426. Dansk Svineproduktion, Den rullende Afproevning, 29.04.1999, 31 p.

Mattsson, B., Lundeheim, N. \& Andersson, K. 2005. Hampshire (homozygot bärare av RN-genen, Quality Genetics) eller Duroc (DanAvl) som faderras. En jämförelse av produktionsresultat och köttkvalitet. Pig Praktiskt Inriktade Grisförsök nr. 35 April 2005. 8 p.

http://www.svenskapig.se/filearchive/2/241/pig35.pdf.

MTT2004. Rehutaulukot ja ruokintasuositukset 2006. Mtt:n selvityksiä 86, 82 p. https://portal.mtt.fi/portal/page/portal/MTT/JULKAISUT/MTT_SELVITYKSIA/VK_2004/mtts86.pdf

Nielsen, E.K. 1986. Foderets formalingsgrad, form og fodringsmetode [Feed structure, pelleting and feeding method). Hyologisk Tikskrift 8, 7: 41-43, 45.

Nielsen, E.K. \& Ingvartsen, K.L. 2000. Effect of cereal type, disintegration method and pelleting on stomach content, weight and ulcers and performance in growing pigs. Livestock Production Science 66: 271-282.

Noblet, J. \& Milgen, J. van. 2004. Energy value of pig feeds: Effect of pig body weight and energy evaluation system. Journal of Animal Science 82 (E. Suppl.): E229-E238.

Nyachoti, C.M., Zijlstra, R.T., De Lange, C.F.M. \& Patience, J.F. 2004. Voluntary feed intake in growing-finishing pigs: A review of the main determining factors and potential approaches for accurate predictions. Canadian Journal of Animal Science 84: 549-566.

O'Doherty, J.V., McGlynn, S.G. \& Murphy, D. 2000. The effect of expander processing and pelleting on the nutritive value of feed for growing and finishing pigs. Journal of the Science of Food and Agriculture 81: 135-141. Siljander-Rasi, H. 2005. Suurin ero lihakkuudessa. Sika 1/2005: 6-9.

Skoch, E.R., Binder, S.F., Deyoe, C.W., Allee, G.L. \& Behnke, K.C. 1983. Effects of pelleting conditions on performance of pigs fed a corn-soybean meal diet. Journal of Animal Science 57: 922-928.

Tauson, A.-H., Chwalibog, A., Jakobsen, K. \& Thorbek, G. 1998. Pattern of protein retention in growing boars of different breeds, and estimation of maximum protein retention. Archives of Animal Nutrition 51: 253-262.

Wilfart, A., Montagne, L., Simmins, P.H., Milgen, J. van \& Noblet, J. 2007. Sites of nutrient digestion in growing pigs: Effect of dietary fiber. Journal of Animal Science 85: 976-983.

Wondra, K.J., Hancock, J.D., Behnke, K.C. \& Stark, C.R. 1995a. Effect of mill type and particle size uniformity on growth performance, nutrient digestibility, and stomach morphology in finishing pigs. Journal of Animal Science 73: 2564-2573.

Wondra, K.J., Hancock, J.D., Behnke, K.C., Hines, R.H. \& Stark, C.R. 1995b. Effects of particle size and pelleting on growth performance, nutrient digestibility, and stomach morphology in finishing pigs. Journal of Animal Science 73: 757-763.

TIKE. 2007. Maa- ja metsätalousministeriön tietopalvelukeskus. Sianlihamarkkinat. Hintapuntari 8/2007, 19 p. 
Taulukko 2. Rehun olomuodon ja energiaväkevyyden vaikutus kasvuun ja rehunkulutukseen alku- ja loppukasvatuksessa ja koko kasvatuksen aikana

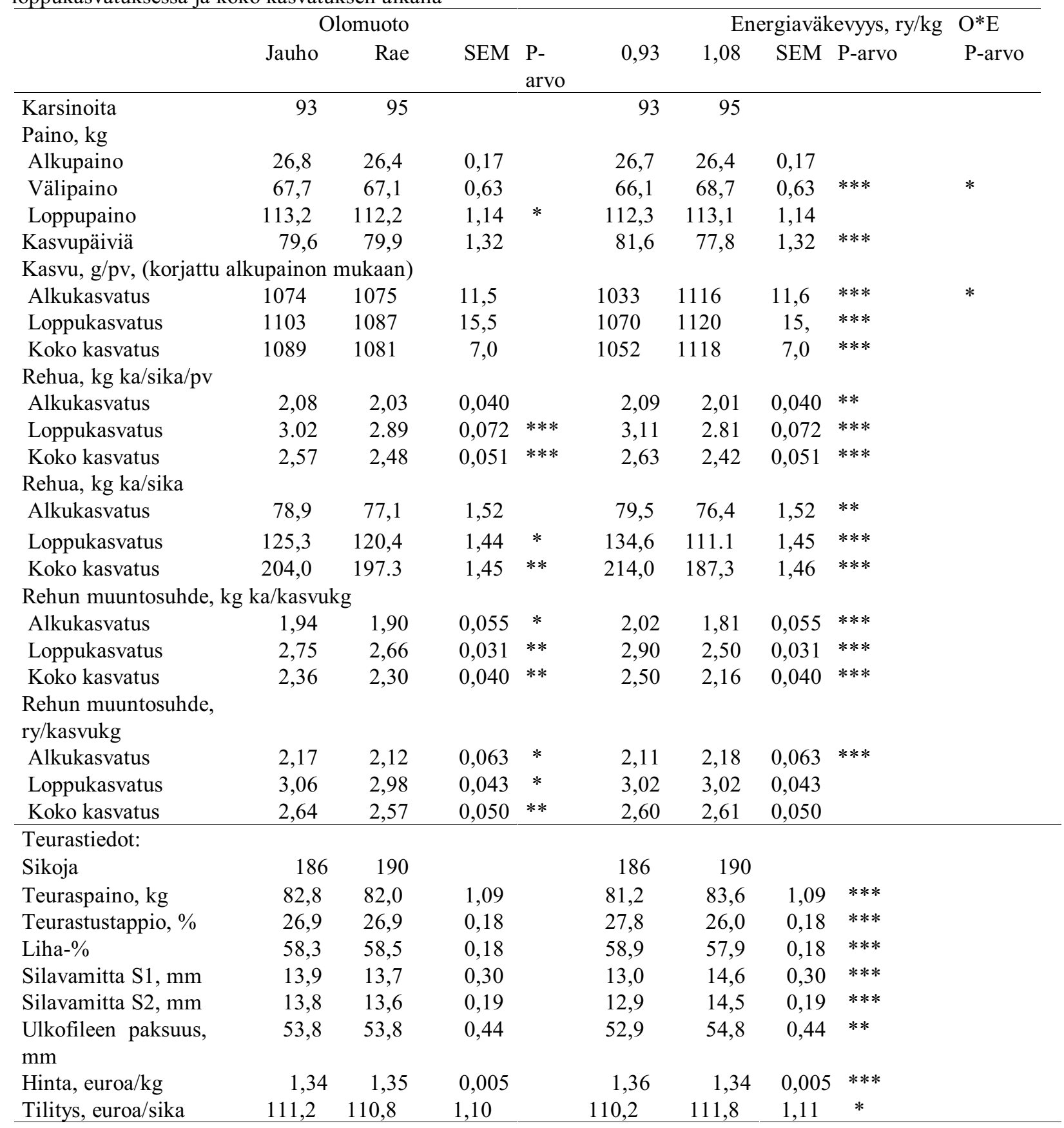

${ }^{a}$ SEM-arvo on pienemmälle havaintomäärälle. 
Taulukko 3. Sian isärodun ja rehun energiaväkevyyden vaikutus energian saantiin ja rehun käyttöön alku- ja loppukasvatuksessa ja koko kasvatuksen aikana

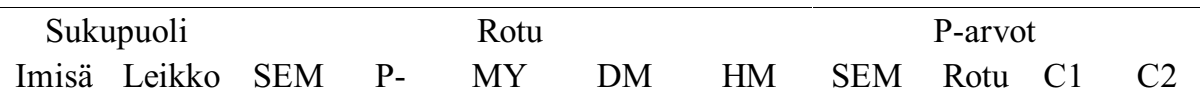

\begin{tabular}{|c|c|c|c|c|c|c|c|c|c|c|c|}
\hline & & & & arvo & & & & & & & \\
\hline Karsinoita & 94 & 94 & & & 70 & 72 & 46 & & & & \\
\hline Paino, kg & & & & & & & & & & & \\
\hline Alkupaino & 26,3 & 26,9 & 0,017 & $*$ & 26,2 & 26,8 & 26,8 & 0,23 & $*$ & $*$ & \\
\hline Välipaino & 66,3 & 68,5 & 0,63 & $* *$ & 66,1 & 68,1 & 68,0 & 0,78 & $* *$ & $* *$ & \\
\hline Loppupaino & 112,2 & 113,2 & 1,14 & & 111,5 & 113,6 & 112,9 & 1,22 & $* *$ & $* *$ & \\
\hline Kasvupäiviäb & 82,1 & 77,4 & 1,32 & $* * *$ & 80,1 & 81,3 & 77,9 & 1,47 & $* *$ & & $* *$ \\
\hline Kasvu, g/pv, (korjattu & upainon & mukaan & & & & & & & & & \\
\hline Alkukasvatus & 1057 & 1092 & 11,5 & $*$ & 1053 & 1082 & 1089 & 15,0 & $*$ & $*$ & \\
\hline Loppukasvatus & 1051 & 1139 & 15,6 & $* * *$ & 1091 & 1066 & 1128 & 18,7 & $* *$ & & $* * *$ \\
\hline Koko kasvatus & 1054 & 1116 & 7,0 & $* * *$ & 1073 & 1075 & 1106 & 9,7 & $* *$ & & $*$ \\
\hline Rehua, ka/sika/pv & & & & & & & & & & & \\
\hline Alkukasvatus & 1,99 & 2,11 & 0,040 & $* * *$ & 1,89 & 2,12 & 2,14 & 0,047 & $* * *$ & $* * *$ & \\
\hline Loppukasvatus & 2,78 & 3,14 & 0,072 & $* * *$ & 2,83 & 2,94 & 3,09 & 0,078 & $* * *$ & $* * *$ & $* *$ \\
\hline Koko kasvatus & 2,41 & 2,63 & 0,050 & $* * *$ & 2,38 & 2,56 & 2,63 & 0,055 & $* * *$ & $* * *$ & \\
\hline Rehua, ka kg/sika & & & & & & & & & & & \\
\hline Alkukasvatus & 75,7 & 80,3 & 1,52 & $* * *$ & 72,0 & 80,7 & 81,3 & 1,77 & $* * *$ & $* * *$ & \\
\hline Loppukasvatus & 122,1 & 123,6 & 1,44 & & 118,2 & 126,5 & 123,9 & 2,01 & $* *$ & $* *$ & \\
\hline Koko kasvatus & 197,6 & 203,7 & 1,44 & $* *$ & 190,7 & 207,3 & 203,9 & 2,02 & $* * *$ & $* * *$ & \\
\hline Rehun muuntosuhde, & $\mathrm{ka} / \mathrm{kasv}$ & & & & & & & & & & \\
\hline Alkukasvatus & 1,89 & 1,94 & 0,055 & $* *$ & 1,81 & 1,96 & 1,98 & 0,058 & $* * *$ & $* * *$ & \\
\hline Loppukasvatus & 2,65 & 2,76 & 0,031 & $* * *$ & 2,61 & 2,77 & 2,73 & 0,040 & $* * *$ & $* * *$ & \\
\hline Koko kasvatus & 2,30 & 2,36 & 0,040 & $* *$ & 2,24 & 2,38 & 2,37 & 0,044 & $* * *$ & $* * *$ & \\
\hline Rehun muuntosuhde & kasvuk & & & & & & & & & & \\
\hline Alkukasvatus & 2,12 & 2,17 & 0,063 & $*$ & 2,03 & 2,19 & 2,21 & 0,065 & $* * *$ & $* * *$ & \\
\hline Loppukasvatus & 2,96 & 3,09 & 0,043 & $* * *$ & 2,91 & 3,10 & 3,06 & 0,051 & $* * *$ & $* * *$ & \\
\hline Koko kasvatus & 2,57 & 2,64 & 0,050 & $* *$ & 2,50 & 2,66 & 2,65 & 0,054 & $* * *$ & $* * *$ & \\
\hline Teurastiedot: & & & & & & & & & & & \\
\hline Sikoja & 188 & 188 & & & 140 & 144 & 92 & & & & \\
\hline Teuraspaino, kg & 82,5 & 82,3 & 1,09 & & 81,4 & 83,3 & 82,5 & 1,17 & $* *$ & $* *$ & \\
\hline Teurastustappio, $\%$ & 26,6 & 27,2 & 0,17 & $* * *$ & 27,0 & 26,8 & 26,8 & 0,23 & & & \\
\hline Liha- $\%$ & 59,3 & 57,5 & 0,18 & $* * *$ & 59,3 & 57,8 & 58,0 & 0,25 & $* * *$ & $* * *$ & \\
\hline Silavamitta S1, mm & 13,2 & 14,4 & 0,30 & $* * *$ & 12,1 & 14,7 & 14,6 & 0,38 & $* * *$ & $* * *$ & \\
\hline Silavamitta S2, mm & 12,8 & 14,6 & 0,19 & $* * *$ & 12,3 & 14,4 & 14,4 & 0,26 & $* * *$ & $* * *$ & \\
\hline $\begin{array}{l}\text { Ulkofileen paksuus, } \\
\text { mm }\end{array}$ & 55,0 & 52,7 & 0,44 & $* * *$ & 52,4 & 53,9 & 55,3 & 0,60 & $* *$ & $* * *$ & \\
\hline Hinta, euroa/kg & 1,37 & 1,33 & 0,005 & $* * *$ & 1,36 & 1,34 & 1,34 & 0,007 & $* * *$ & $* * *$ & \\
\hline Tilitys, euroa/sika & 112,7 & 109,3 & 1,10 & $* * *$ & 110,7 & 111,4 & 110,8 & 1,26 & & & \\
\hline
\end{tabular}

${ }^{a}$ SEM-arvo on pienimmälle havaintomäärälle. Sukupuolen ja isärodun välillä ei ollut merkitseviä yhdysvaikutuksia Kontrastit: C1 MY vs. DM+HM; C2 DM vs. HM 